\title{
PENGGUNAAN KALIMAT EFEKTIF \\ DALAM KARANGAN DESKRIPSI SISWA KELAS X AP3 SMK NEGERI 1 KOTA JAMBI TAHUN AJARAN 2017/2018
}

\author{
Fitri Rahmadani ${ }^{1}$, Erlina Zahar $^{2}$, Sujoko $^{3}$ \\ Program Studi Pendidikan Bahasa dan Sastra Indonesia, \\ Fakultas Keguruan dan Ilmu Pendidikan, Universitas Batanghari, \\ Jambi \\ frahmadani63@yahoo.com \\ erlina_zahar@yahoo.co.id \\ sujoko1987@yahoo.com
}

\begin{abstract}
The purpose of this research is to describe the use of effective sentence based on the feature of effective sentences in students' descriptive writing at class X AP3 SMK Negeri 1 Kota Jambi Academic Year 2017/2018. This research is descriptive qualitative. The data is taken from the students writing in a form of sentence in students descriptive writing. Based on the result of the analysis, it can be concluded that there are many mistakes found in using effectve sentence in students descriptive writing at class X AP3 SMK Negeri 1 Kota Jambi Academic Year 2017/2018. From the five effective features of sentence, they are: unity, parallel, stressing in sentence, provident and variation. Based on this result, it is suggested that the students should pay more attention in using effective sentence in writing descriptive text or other texts. Moreover, it is also suggested that the students should pay more attention in making good sentence.
\end{abstract}

Key Words: analysis, effective sentence, descriptive text.

\footnotetext{
${ }^{1}$ Mahasiswa Program Studi Pendidikan Bahasa dan Sastra Indonesia, Fakultas Keguruan dan Ilmu Pendidikan, Universitas Batanghari, Jambi

${ }^{2}$ Dosen Program Studi Pendidikan Bahasa dan Sastra Indonesia, Fakultas Keguruan dan Ilmu Pendidikan, Universitas Batanghari, Jambi

${ }^{3}$ Dosen Program Studi Pendidikan Bahasa dan Sastra Indonesia, Fakultas Keguruan dan Ilmu Pendidikan, Universitas Batanghari, Jambi
} 
Kata Kunci: analsisis, kalimat efektif, karangan deskripsi

\section{PENDAHULUAN}

Analisis kesalahan berbahasa merupakan kegiatan pengkajian segala aspek penyimpangan berbahasa itu sendiri."Kita hendaklah benar-benar menyadari bahwa orang tidak dapat belajar bahasa tanpa sama sekali berbuat kesalahan-kesalahan secara sistematis" (Tarigan, 2011: 126). Kesalahan tersebut merupakan bagian-bagian komposisi yang menyimpang dari norma baku atau norma terpilih dari performansi bahasa orang dewasa. Kesalahan mencerminkan tingkat perkembangan penguasaan kaidah gramatikal si penutur, sehingga menjadi satu persoalan penting dalam proses pembelajaran bahasa yang perlu mendapat perhatian cukup serius, baik dari pihak pembelajar sendiri terlebih dari pihak pengajar. "Analisis kesalahan berbahasa adalah suatu teknik untuk mengidentifikasikan, mengklasifikasikan, dan menginterprestasikan secara sistematis kesalahan-kesalahan yang dibuat siswa yang sedang belajar bahasa kedua atau bahasa asing dengan menggunakan teoriteori dan prosedur-prosedur berdasarkan linguistik" (Crystal dalam Pateda, 1989:32). Kesalahan berbahasa akan sering terjadi apabila pemahaman seseorang tentang sistem bahasa kurang. Kesalahan berbahasa dapat berlangsung lama apabila tidak diperbaiki.

Analisis kesalahan berbahasa sangat diperlukan dalam pelajaran yang diajarkan di sekolah terutama dalam menulis karangan. Karena dengan analisis kesalahan berbahasa para guru dapat mengatasi kesulitan yang ada pada siswa agar tidak terjadi lagi kesalahan berbahasa. Salah satu kesalahan berbahasa yaitu kalimat.
Kalimat merupakan unsur terpenting dalam sebuah wacana."Kalimat adalah satuan sintaksis yang dibangun oleh konstituen dasar biasanya berupa klausa, dilengkapi dengan konjungsi bila diperlukan, disertai dengan intonasi final (deklaratif, interogatif, imperatif atau interjektif)" (Chaer, 2008: 5). Kalimat disusun berdasarkan unsur-unsur berupa kata, frasa, dan klausa."Kalimat adalah satuan gramatikal yang dibatasi oleh adanya jeda panjang yang disertai nada akhir naik atau turun" (Putrayasa, 2008: 20). Sekurang-kurangnya kalimat dalam ragam resmi, baik lisan maupun tertulis, harus memiliki subjek (S) dan predikat (P) kalau tidak memiliki unsur subjek dan unsur predikat, pernyataan itu bukanlah kalimat."Dalam wujud tulisan, kalimat diucapkan dalam suara naik turun dan keras lembut disela jeda, diakhiri intonasi akhir yang diikuti oleh kesenyapan yang mencegah terjadinya perpaduan, baik asimilasi bunyi maupun proses fonologis lainnya" (Alwi, 2000: 311). Dalam wujud tulisan berhuruf latin kalimat dimulai dengan huruf kapital dan diakhiri dengan tanda titik, tanda tanya dan tanda seru.

Jika penutur ingin menyakinkan dan menyenangkan mitra tutur dalam berbahasa, penutur harus pandai membentuk kalimat yang tepat sasaran, karena dengan menggunakan kalimat yang baik, benar, dan jelas akan mempermudah penutur berkomunikasi dengan orang lain dan tentu juga harus mahir dalam menyusun kalimat menggunakan katakata. "Kalimat efektif adalah kalimat yang memiliki kemampuan untuk menimbulkan gagasan-gagasan pada pikiran pendengar atau pembaca seperti apa yang ada dalam pikiran pembaca atau penulis" (Arifin, 2000: 89). Sebuah kalimat efektif harus memiliki kemampuan untuk menimbulkan 
kembali gagasan-gagasan pada pikiran pendengar atau pembaca."Kalimat efektif adalah kalimat yang disusun secara sadar untuk mencapai daya informasi yang diinginkan oleh penulis terhadap pembacanya" (Fuad dalam Dalman, 2009: 58). Konsep kalimat efektif dikenal dalam hubungan fungsi kalimat selaku alat komunikasi."Kalimat efektif adalah kalimat yang dengan tepat mampu menyampaikan gagasan dari seorang penulis sehingga menimbulkan gagasan yang sama tepatnya dengan pembaca" (Kuncoro dalam Pujiono, 2009). Artinya, kalimat efektif adalah kalimat yang dapat mencapai sasarannya dengan baik sebagai alat komunikasi.

Kalimat efektif merupakan kalimat yang mampu membuat isi dan maksud yang disampaikannya itu tergambar lengkap dalam pikiran isi penerima atau pembaca persis seperti yang disampaikan. Adapun ciri-ciri kalimat efektif (Akhadiah dalam Dalman, 1999: 116-117) yaitu: kesepadanan dan kesatuan, kesejajaran (paralelisme), penekanan dalam kalimat, kehematan, kevariasian.

Berdasarkan ciri-ciri kalimat efektif di atas, dapat disimpulkan bahwa ciri-ciri kalimat efektif ada lima, yaitu kesepadanan, kesejajaran, penekanan dalam kalimat, kehematan dan kevariasian. Ciri-ciri kalimat efektif ini yang digunakan untuk menganalisis kesalahan terdapat di dalam karangan deskripsi.

Sesuatu yang dapat dideskripsikan tidak hanya terbatas pada apa yang dapat dilihat dan didengar saja, tetapi juga yang dapat dirasa dan dipikir. "Deskripsi adalah bentuk tulisan yang bertujuan memperluas pengetahuan dan pengalaman pembaca dengan jalan melukiskan hakikat objek yang sebenarnya" (Finoza dalam Dalman, 2008: 233-247). Karangan deskripsi merupakan salah satu jenis karangan yang harus dikuasai siswa."Karangan deskripsi adalah karangan yang melukiskan sesuatu secara objektif sampai kepada detaildetailnya secara mendalam dan sistematis sesuai dengan keadaan yang sebenarbenarnya tentang sesuatu yang dilukiskan itu" (Hartono, 2000: 78). Karangan ini bertujuan untuk memberikan perincian tentang objek sehingga seakan-akan mereka ikut melihat, mendengar, merasakan atau mengalami langsung objek tersebut."Karangan deskripsi atau pemerian merupakan sebuah bentuk tulisan yang bertalian dengan usaha para penulis untuk memberikan perincianperincian dari objek yang sedang dibicarakan" (Keraf, 2005: 93). Deskripsi merupakan karangan yang sifatnya melukiskan atau menggambarkan suatu tempat, keadaan, benda secara jelas dan rinci. Jadi, dapat disimpulkan bahwa karangan deskripsi adalah karangan yang menggambarkan sesuatu berdasarkan kesan-kesan pengamatan suatu tempat, keadaan, benda secara jelas dan rinci sehingga pembaca seolah-olah melihat, mendengar dan merasakan seperti yang ditulis dalam karangan.

Pembelajaran Bahasa Indonesia di Sekolah di antaranya mempelajari keterampilan menulis. Pembelajaran keterampilan menulis dibutuhkan bagi siswa agar terampil menulis. Selain itu, menulis juga dibutuhkan oleh setiap manusia. Keterampilan menulis tidak kalah penting dari pembelajaran keterampilan berbahasa lainnya, seperti keterampilan menyimak, berbicara dan keterampilan membaca. Oleh karena itu, pembelajaran keterampilan menulis memiliki porsi yang cukup menentukan dalam pelajaran bahasa Indonesia di sekolah.

Keterampilan menulis dibutuhkan bagi siswa di sekolah. Dalam menulis, tulisan yang ditulis haruslah jelas, ringkas dan mudah dipahami oleh pembaca. 
Suatu tulisan yang mudah dipahami adalah tulisan yang ditulis dengan kalimat yang efektif.

Kalimat efektif adalah kalimat yang mampu membuat isi atau maksud yang disampaikan tergambar lengkap dalam pikiran si penerima atau pembaca, persis seperti apa yang disampaikan. Kalimat dikatakan efektif apabila berhasil menyampaikan pesan, gagasan, perasaan, maupun pemberitahuan sesuai dengan maksud penulis. Untuk itu penyampaian harus memenuhi syarat sebagai kalimat yang baik, yaitu strukturnya benar, pilihan katanya tepat dan ejaannya harus benar. Penggunaan kalimat efektif menjadi penting dalam suatu karangan.

Tulisan yang efektif adalah tulisan yang mudah dipahami oleh orang lain. Adanya tulisan yang tidak efektif, menyebabkan pengaburan makna. Oleh karena itu, penguasaan kalimat efektif sangat penting dalam pembelajaran keterampilan menulis, terutama menulis karangan deskripsi di kelas X AP3 SMK Negeri 1 Kota Jambi tahun ajaran 2017/2018. Keterampilan menulis siswa akan terukur dari mampu tidaknya dia menulis dengan menggunakan kalimat yang efektif.

Berdasarkan latar belakang yang telah dikemukakan, maka fokus penelitian ini yaitu analisis penggunaan kalimat efektif pada karangan deskripsi siswa kelas X AP3 SMK Negeri 1 Kota Jambi tahun ajaran 2017/2018. Adapun pertanyaan penelitian ini, bagaimanakah kesalahan penggunaan kalimat efektif pada karangan deskripsi siswa kelas X AP3 SMK Negeri 1 Kota Jambi tahun ajaran 2017/2018?

Berdasarkan latar belakang masalah di atas, penelitian ini bertujuan untuk mendeskripsikan penggunaan kalimat efektif pada karangan deskripsi siswa kelas X AP3 SMK Negeri 1 Kota Jambi Tahun Ajaran 2017/2018.
Kajian mengenai penggunaan kalimat efektif pada karangan deskripsi sudah pernah diteliti oleh peneliti sebelumnya. Pertama, Rini Setianingrum dari Universitas Islam Negeri Syarif Hidayatullah Jakarta dalam skripsinya yang berjudul Penggunaan Kalimat Efektif dalam Karangan Argumentasi "Pemilihan Anggota Legislatif dari Kalangan Selebritas" Siswa Kelas X SMK Triguna Utama Ciputat. Kedua, Mazniwati dari Universitas Maritim Raja Ali Haji Tanjung Pinang dalam skripsinya yang berjudul Analisis Kesalahan Penggunaan Kalimat Efektif dalam Karangan Deskripsi Siswa Kelas VIII Sekolah Menengah Pertama Negeri 4 Penuba Lingga Tahun Pelajaran 2013/2014" Tahun 2014. Ketiga, Widi Widiastuti, Universitas Pendidikan Indonesia Purwakarta dalam skripsinya yang berjudul Meningkatkan Kemampuan Membaca dan Menulis Karangan Narasi dengan Penerapan Model Pembelajaran Kooperatif Tipe Think-Pair-Share. Keempat, Arlis Muryani dari Universitas Negeri Semarang dalam skripsinya yang berjudul Peningkatan Keterampilan Menulis Karangan Deskripsi dengan Teknik Kata Kunci dan Media Objek Langsung pada Siswa Kelas V SD Negeri 7 Wirosari Kabupaten Grobongan" Tahun 2010. Berdasarkan hasil kajian yang telah dilakukan. Penelitian tersebut tidak jauh berbeda dengan penelitin ini. Namun terdapat perbedaan yaitu pada objek dan subjek penelitian.

\section{METODE PENELITIAN}

Jenis penelitian ini adalah deskriptif kualitatif. Penelitian deskriptif kualitatif merupakan metode yang digunakan untuk meneliti objek untuk mendapatkan tujuan pemahaman. "Pendekatan Deskriptif, yaitu penelitian yang dilakukan semata-mata hanya 
berdasarkan fakta-fakta yang ada atau fenomena yang secara empiris hidup pada penuturnya sehingga yang dihasilkan atau yang dicatat berupa peran bahasa yang biasa dikatakan sifatnya seperti potret atau paparan seperti apa adanya" (Sudaryanto dalam Muhammad, 2011: 192). Dengan menggunakan metode penelitian deskriptif kualitatif peneliti dapat memahami bagaimana objek penelitian pada suatu konteks tertentu yang ada dalam objek penelitian. Penelitian kualitatif menekankan pada penelitian struktur bukan pada penelitian angka."Penelitian kualitatif adalah peristiwa komunikasi atau berbahasa karena peristiwa ini melibatkan tuturan, makna semantik tutur, orang yang bertutur, maksud yang bertutur, situasi tutur, peristiwa tutur, tindak tutur, dan latar tuturan" (Muhammad, 2011: 31). Dengan menggunakan metode penelitian deskriptif kualitatif peneliti dapat memahami bagaimana objek penelitian pada suatu konteks tertentu yang ada dalam objek penelitian.

Data dalam penelitian ini adalah kalimat efektif dalam karangan deskripsi siswa kelas X AP3 SMK Negeri 1 Kota Jambi tahun ajaran 2017/2018. Teknik pengumpulan data merupakan langkah utama dalam melakukan penelitian. "Teknik pengumpulan data merupakan langkah yang paling strategis dalam penelitian, karena tujuan utama dari penelitian adalah mendapatkan data" (Sugiyono, 2015: 62). Dalam pengumpulan data, penulis melampirkan lembar identifikasi data berupa langkahlangkah dalam pengumpulan data yang berhubungan dengan kesalahan penggunaan kalimat efektif pada karangan deskripsi siswa kelas X AP3 SMK Negeri 1 Kota Jambi tahun ajaran 2017/2018. Teknik pengumpulan data dalam penelitian ini dilakukan dengan langkah- langkah yaitu wawancara, studi kepustakaan, dan dokumentasi.

"Analisis data merupakan suatu proses mengatur urutan data, mengorganisasikannya ke dalam suatu pola, kategori, dan satuannya" (Patton dalam Muhammad, 2011: 221). Analisis data merupakan upaya yang dilakukan penulis untuk mengklasifikasikan dan mengelompokkan data. Adapun langkahlangkah yang dilakukan dalam manalisis data adalah sebagai berikut: 1) membaca dengan pemahaman sumber-sumber yang berkaitan dengan dengan ciri-ciri kalimat efektif; 2) membaca dan mencermati dokumen data berupa tulisan deskripsi sepuluh orang siswa kelas X AP3 SMK Negeri 1 Kota Jambi; 3) menandai kesalahan penulisan kalimat efektif yang terdapat dalam data penelitian; 4) mengklasifikasi kesalahan penggunaan kalimat efektif pada karangan deskripsi siswa kelas X AP3 SMK Negeri 1 Kota Jambi; 5) mentabulasikan data yang telah diklasifikasi; 6) menganalisis kesalahan penggunaan kalimat efektif berdasarkan ciri-ciri kalimat efektif; 7) mendeskripsikan kesalahan penggunaan kalimat efektif pada karangan deskripsi siswa kelas X AP3 SMK Negeri 1 Kota Jambi.; 8) mengabsahkan data dengan uji keabsahan data; 9) merumuskan kesimpulan.

\section{HASIL DAN PEMBAHASAN}

Berdasarkan analisis data yang dilakukan, maka teridentifikasi kesalahankesalahan dalam penulisan ciri kalimat efektif dari ciri kesatuan, kesejajaran, penekanan dalam kalimat. Kesalahan penggunaan kalimat efektif terdapat 18 kutipan dari 10 karangan siswa, akan tetapi yang dibahas hanya 8 kutipan. Berikut adalah kutipan yang menyatakan kesalahan penggunaan kalimat efektif berdasarkan lima ciri-ciri kalimat efektif. 
1. Analisis ciri kesatuan kalimat efektif pada karangan deskripsi siswa kelas $\mathrm{X}$ AP3 SMK Negeri 1 Kota Jambi tahun ajaran 2017/2018.

(1.1) "Kertas merupakan benda yang terbuat dari serat/bubur kayu yang diolah. Kertas umumnya berwarna putih tapi terkadang ada yang berwarna seperti merah, kuning, hijau. Kertas digunakan untuk menulis \& menggambar. Kertas berbentuk persegi panjang pada umumnya, tapi kertas dapat dibentuk sesuka hati. Kelemahan dari kertas adalah jika ia terkena air maka akan sobek". (AA)

Kutipan (1.1) dinyatakan tidak sesuai dengan ciri-ciri kalimat efektif, dalam kutipan tersebut tidak memiliki kesatuan antarusur-unsurnya. Hal tersebut diketahui berdasarkan unsur-unsur pembentuk kalimatnya tidak memiliki kepaduan atau keselarasan, jika terdapat kesatuan antarunusr maka akan terbentuk satu kesatuan gagasan ide yang padu. Jika kalimat kertas umumnya berwarna putih tapi terkadang ada yang berwarna seperti merah, kuning, hijau tersebut diperbaiki dengan memperhatikan kesatuan antarunsur kalimatnya, maka kalimat tersebut menjadi "Pada umumnya kertas berwarna putih, tetapi ada juga yang berwarna merah, kuning dan hijau". Agar kalimat memiliki kesatuan antar usnurnya, sebaiknya ditambahkan 'kata depan' dan 'kata penghubung', sehingga kalimat menjadi efektif dan mudah dibaca serta dimengerti oleh pembaca.

(1.2) "Buah kersen merupakan buah yang memiliki nama ilmiah Muntigia Calabura. Buah ini berbentuk bulat kecil dan berwarna hijau saat baru tumbuh. Menjelang matang, warna buah ini akan menguning dan perlahan-lahan menjadi merah ketika matang. Tekstur buah ini sangat lembut dan mirip seperti biji-bijian yang bentuknya sangat kecil, serta mempunyai rasa yang manis". (MU)

Kutipan (1.2) dinyatakan tidak sesuai dengan ciri ciri kalimat efektif dalam kutipan tersebut tidak memiliki kesatuan antarusur-unsurnya. Hal tersebut diketahui berdasarkan unsur-unsur pembentuk kalimatnya tidak memiliki kepaduan atau keselarasan, jika terdapat kesatuan antarunusr maka akan terbentuk satu kesatuan gagasan ide yang padu. Jika kalimat Buah kersen merupakan buah yang memiliki nama ilmiah Muntigia Calabura tersebut diperbaiki dengan memperhatikan kesatuan antarunsur kalimatnya, maka kalimat tersebut menjadi. "Buah kersen memiliki nama ilmiah yaitu Muntigia Calabura".

2. Analisis ciri kesejajaran kalimat efektif pada karangan deskripsi siswa kelas $\mathrm{X}$ AP3 SMK Negeri 1 Kota Jambi tahun ajaran 2017/2018.

(2.1) "Tas merupakan benda untuk digunakan sebagai tempat barangbarang, sebagai salah satu dalam fashion.Tas memiliki banyak fungsi seperti yang telah disebutkan tadi. Tas juga dapat digunakan oleh semua kalangan dan tas biasanya selalu menjadi hal penting jika kita ingin berpergian. Tas memiliki banyak motif dan bentuk, dan memiliki banyak macam dikalangannya masing-masing. Tas sangat mudah ditemukan dimanapun termasuk di pasar dan tempat accessories lainnya. Tas juga memiliki harga yang berfariasi, harga tas biasanya 
tergantung dengan bahan dan motifnya". (M)

Kutipan (2.1) dinyatakan tidak sesuai dengan ciri-ciri kalimat efektif karena tidak memiliki kesejajaran kalimat. Jika kalimat tersebut memiliki kesejajaran, maka unsur-unsur yang setara akan ditempatkan secara sejajar. Jika kalimat tersebut diperbaiki dengan kesejajaran yang tepat, maka akan menjadi "Tas memiliki berbagai motif dan bentuk, dan tas juga memiliki banyak macam dikalangannya".

"Piring merupakan alat bantu manusia untuk makanan. Namun piring ada yang terbuat dari kaca dan tanah liat. Piring memiliki beragam bentuk dan ukuran. Piring selain untuk makan juga dapat digunakan sebagai hiasan ruangan, piring antik salah satunnya, piring yang berusia ratusan tahun.Piring merupakan salah satu barang penting yang menghiasi kehidupan manusia". (EA)

Kutipan (2.2) dinyatakan tidak sesuai dengan ciri-ciri kalimat efektif karena tidak memiliki kesejajaran kalimat. Jika kalimat tersebut memiliki kesejajaran, maka unsur-unsur yang setara akan ditempatkan secara sejajar. Penggunaan kata "namun" kurang tepat, karena kata tersebut memiliki hubungan pertentangan bukan kesejajaran. Untuk memperbaiki kutipan tersebut, kata namun sebaiknya diganti dengan kata 'dan', sehingga menjadi "Piring ada yang terbuat dari kaca dan ada juga yang terbuat dari tanah liat".

3. Analisis ciri penekanan dalam kalimat efektif pada karangan deskripsi siswa kelas X AP3 SMK Negeri 1 Kota Jambi tahun ajaran 2017/2018:

(3.1) "Jam dinding merupakan benda yang digunakan oleh semua orang untuk menunjukkan waktu. Jam dinding biasanya sering dijumpai di rumah, kantor, sekolah dan lain-lain. Di dalam jam tersebut terdiri dari 3 jarum yang menunjukkan waktu, baterai, pengatur waktu angka/nomor waktu. Jam dinding biasanya dan sering kita lihat itu berbentuk lingkaran atau persegi. Dan jarumjarum yang menunjukkan waktu didalam jam tersebut berbedabeda. Jarum pendek menunjukkan jam, jarum yang panjang dan bergerak pelan menunjukkan menit, sedangkan jarum panjang yang bergerak agak cepat menunjukkan detik". (JS)

Kutipan (3.1) dinyatakan tidak sesuai dengan kalimat efektif karena kutipan tersebut tidak memiliki penekanan dalam kalimat. Seharusnya jika memiliki penekanan kalimat, kalimat tersebut diberi penegasan untuk mendapat perhatian dari pendengar atau pembaca. Sehingga akan menjadi kalimat yang memiliki penekanan dalam kalimat yaitu "Jarum yang menunjukkan waktu di dalam jam berbeda-beda".

(3.2) "Gajah mempunyai belalai yang panjang, berwarna abu-abu. Mempunyai bentuk tubuh yang besar. Termasuk dalam golongan herbivora. Kita dapat menjumpai di kebun binatang atau hutan. Salah satu ciri khasnya yaitu: memiliki gading, ia biasa mengambil makanannya dengan menggunakan hidung belalainya. Mereka hidup secara berkelompok.Pada umumnya banyak manusia yang memburunya 
hanya untuk mendapatkan gadingnya, ia salah satu yang dilestarikan". (RS)

Kutipan (3.2) dinyatakan tidak sesuai dengan cirri-ciri kalimat efektif karena kutipan tersebut tidak memiliki penekanan dalam kalimat.Seharusnya jika memiliki penekanan kalimat, kalimat tersebut diberi penegasan untuk mendapat perhatian dari pendengar atau pembaca. Sehingga akan menjadi kalimat yang memiliki penekanan yaitu "Gajah dapat kita jumpai di kebun binatang dan hutan".

4. Analisis ciri kehematan kalimat efektif pada karangan deskripsi siswa kelas $\mathrm{X}$ AP3 SMK Negeri 1 Kota Jambi tahun ajaran 2017/2018:

(4.1) "Buku merupakan lembaranlembaran kertas yang digabungkan menjadi satu.Buku ada yang tebal dan ada yang tipis.Buku adalah gudang ilmu.Di dalam buku terdapat banyak ilmu, buku juga dapat digunakan sebagai media untuk menulis kenang-kenangan dan masih banyak lagi yang dapat kita lakukan dengan buku”. (AD)

Kutipan (4.1) dinyatakan tidak sesuai dengan ciri-ciri kalimat efektif karena kutipan tersebut tidak memiliki ciri kehematan dalam penggunaan bentuk kata. Hal tersebut diketahui dari penggunaan kata yang tidak tepat, atau pengulangan kata secara berlebihan. Jika kalimat tersebut diperbaiki dengan memperhatikan ciri kehematan kalimat, maka hasilnya adalah sebagai berikut "Di dalam buku banyak terdapat ilmu, buku bisa digunakan sebagai media untuk menulis dan masih banyak lagi kegunaan buku”.
5. Analisis ciri kevariasian kalimat efektif pada karangan deskripsi siswa kelas $\mathrm{X}$ AP3 SMK Negeri 1 Kota Jambi tahun ajaran 2017/2018.

(5.1) "Pensil merupakan benda yang terbuat dari kayu tetapi ada juga yang terbuat dari plastik. Pensil memiliki suatu tulis yang dapat timbul di kertas putih. Kegunaannya menulis dan dapat untuk dimengerti agar lebih jelas dan dapat dibaca. Pensil juga alat pertama ditemui dari pada pena atau lain-lain". (DM)

Kutipan (5.1) dinyatakan tidak sesuai dengan ciri-ciri kalimat efektif karena pada kutipan tersebut tidak mengandung ciri kevariasian kalimat. Seharusnya jika kutipan tersebut mengandung ciri kevariasian kalimat maka akan menjadi sebagai berikut "Pensil adalah suatu alat tulis yang dapat digunakan untuk menulis di kertas yang masih kosong".

\section{SIMPULAN}

Berdasarkan hasil penelitian dan pembahasan, maka dapat disimpulkan bahwa terdapat beberapa kesalahan penggunaan kalimat efektif pada karangan deskripsi siswa kelas X AP3 SMK Negeri 1 Kota Jambi Tahun Ajaran 2017/2018. Sebuah kalimat dapat dikatakan efektif apabila berhasil menyampaikan pesan, gagasan, perasaan maupun pemberitahuan sesuai dengan maksud si pembicara atau penulis. Untuk itu penyampaian harus memenuhi syarat sebagai kalimat yang efektif yaitu memiliki kesatuan, kesejajaran, penekanan dalam kalimat, kehematan dan kevariasian. 


\section{DAFTAR PUSTAKA}

Alwi, Hasan, dkk. (2000). Tata Bahasa Baku Bahasa Indonesia. Jakarta: Balai Pustaka.

Arifin, E. Zaenal dan S. Amran Tasai. (2000). Cermat Berbahasa Indonesia untuk Perguruan Tinggi. Jakarta: Akademika Pressindo.

Chaer, Abdul. (2008). Sintaksis Bahasa Indonesia (Pendekatan Proses). Jakarta: Rineka Cipta.

Dalman. (2014). Keterampilan Menulis. Jakarta: Rajawali Pers.

EJOURNAL-MAZNIWATI 090388201199-FKIP-2014.pdf. Tanggal akses 18 November 2017.

Hartono, Bambang. (2000). Kajian Wacana. Semarang: FBS Unnes.

Henry Guntur dan Djago Tarigan. (1990). Pengajaran Analisis Kesalahan Berbahasa. Bandung: Angkasa.
Keraf, Gorys. (2006). Komposisi. Jakarta: Ikrar Mandiri Abadi.

Muhammad. (2011). Metode Penelitian Bahasa. Yogyakarta: Ar-Ruzz Media.

Pateda, Mansoer. (1989). Analisis Kesalahan. Nusa Tenggara Timur: Nusa Indah.

Putrayasa, Ida Bagus. (2014). Kalimat Efektif (Diksi, Struktur, dan Logika). Bandung: Refika Aditama. Pujiono,

RINISETIANINGRUM-FITK.pdf.

Tanggal akses 18 November 2017.

Setyawan. (2009) Terampil Menulis. Yogyakarta: Graha Ilmu.

Sugiyono. (2016). Memahami Penelitian Kualitatif. Bandung: Alfabeta. 